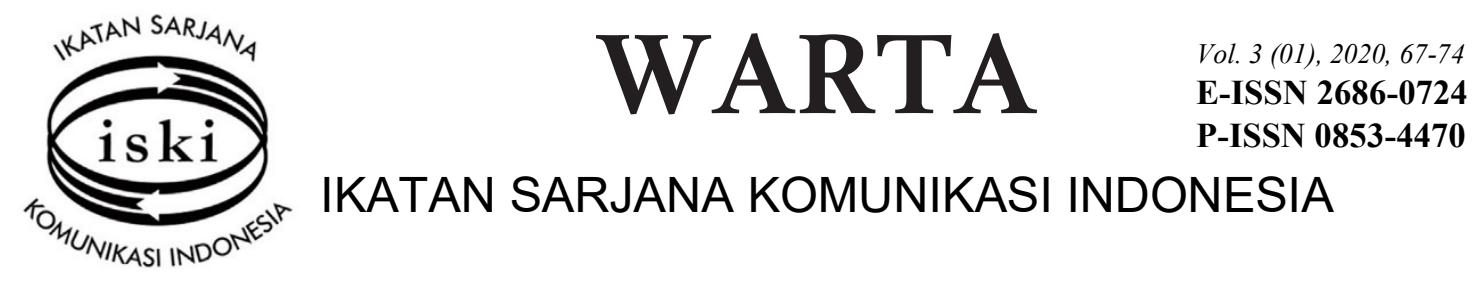

\title{
Makna Logo Dinas Penerangan Tentara Nasional Indonesia Angkatan Laut
}

\author{
http://dx.doi.org/10.25008/wartaiski.v3i01.57
}

\section{Infra Wahdaniah ${ }^{1 *}$, Ahmad Toni², Rajab Ritonga ${ }^{3}$}

${ }^{1,2}$ Pascasarjana Ilmu Komunikasi, Universitas Budi Luhur J1. Raya Ciledug-Kebayoran Lama, Jakarta Selatan 12260 - Indonesia Fakultas Ilmu Komunikasi Universitas Prof. Dr. Moestopo (Beragama)

Jl. Hang Lekir I No. 8 Jakarta Pusat 10270 - Indonesia "e-mail korespondensi: ${ }^{1} 1971600190$ student.budiluhur.ac.id

Submitted: 13/04/2020, Revised: 05/05/2020, Accepted: 03/06/2020 Accredited by Kemristekdikti No. 30/E/KPT/2019

\begin{abstract}
The purpose of this study is to see the meaning of marks found in the logo of the Indonesian Navy Information Service and the role of the logo in encouraging the effectiveness of information to build the good image of the Navy. The marks found in the logo are analyzed and interpreted using the semiotics of Charles Sanders Pierce. Based on the research results, the researcher comes to the conclusion that the meaning of marks, in this case the colors and typography of the logo, accords with the vision and mission of the Navy. The use of red, white, and blue colors, as well as the use of the rudder-shaped object bearing the words "the Navy Information Service", and the globe and ribbon bearing the words "Fast, Precise, and Accurate" on the logo represent the organizational communication of the Navy Information Service in carrying out their duties in accordance with the vision and mission of the Navy. The logo reflects the role of the Navy Information Service as a spokesperson for the Navy to encourage the effectiveness of information service in building the image of the Navy.
\end{abstract}

Keywords: Effectiveness of information; Indonesia navy information service; meaning of marks; semiotics; spokesperson

\section{Abstrak}

Penelitian ini untuk mengetahui makna yang terkandung dalam logo Dinas Penerangan (Dispen) Tentara Nasional Indonesia - Angkatan Laut dan perannya dalam mendorong efektivitas penerangan dalam membangun citra TNI Angkatan Laut. Tanda-tanda pada logo itu dianalisa dan dimaknai menggunakan semiotika Charles Sanders Pierce. Kesimpulan yang didapat dari penelitian ini adalah pemaknaan tanda pada bentuk logo Dinas Penerangan TNI Angkatan Laut, warna dan tipografinya sesuai dengan visi dan misi TNI Angkatan Laut. Penggunaan warna merah, putih, dan biru, serta penggunaan bentuk kemudi dengan tulisan "Penerangan TNI AL", bola dunia, dan pita bertuliskan "Cepat Tepat Akurat" pada logo Dinas Penerangan TNI Angkatan Laut mewakili komunikasi organisasi Dinas Penerangan TNI Angkatan Laut dalam melaksanakan tugasnya dan itu sejalan dengan visi misi TNI Angkatan Laut. Logo itu adalah representasi Dispenal sebagai juru bicara TNI Angkatan Laut yang dapat mendorong efektivitas penerangan dalam membangun citra TNI Angkatan Laut.

Kata kunci: Efektifitas informasi; dinas penerangan TNI AL; makna logo; semiotika, juru bicara

\section{PENDAHULUAN}

Sebagai makhluk sosial manusia selalu berkomunikasi baik secara individu, kelompok, organisasi, institusi swasta maupun pemerintah, masyarakat hingga organisasi terbesar yang disebut negara. Komunikasi menjadi roh kehidupan manusia dalam berhubung-hubungan antara satu sama lain baik secara langsung maupun tidak langsung dengan berbagai cara dan media yang digunakan (Effendy, 
2001, Littlejohn, 2018, Mulyana, 2017).

Bentuk komunikasi tidak langsung misalnya menggunakan gambar, warna, maskot, kode, simbol atau logo. Penggunaan simbol dengan berbagai elemen warna, huruf, kode yang dirangkai dalam bentuk logo menjadi sarana komunikasi yang banyak digunakan. Meski tidak terjadi interaksi dua arah seperti komunikasi secara langsung, logo memberi makna kepada yang melihatnya. Dengan melihat logo tertentu orang telah tahu apa makna yang terkandung dalam logo tersebut.

Logo merupakan pintu masuk dan mencerminkan sebuah brand institusi. Itu sebabnya, logo harus dapat menampilkan pribadi dan jiwa entitas yang diwakilinya (Oscario, 2013). Logo sangat penting sebagai identitas diri dalam berkomunikasi. Logo juga dapat menaikkan citra institusi yang diwakili logo tersebut.

Dinas Penerangan Tentara Nasional Indonesia - Angkatan Laut (Dispenal) sebagai sebuah institusi negara di lingkungan TNI juga memiliki logo. Institusi itu menjalankan sejumlah tugas dan fungsi penerangan militer, salah satunya menjadi juru bicara TNI Angkatan Laut.

Dalam Peraturan Presiden Nomor 66 Tahun 2019 disebutkan, Dispenal bertugas menyelenggarakan pembinaan penerangan yang meliputi: (1) penerangan pasukan, (2) penerangan umum, (3) produksi penerangan, (4) multimedia dan konter opini dalam rangka mendukung tugas TNI Angkatan Laut.

Dispenal dituntut untuk selalu hadir dan mampu berkomunikasi secara efektif dalam mengkomunikasikan berbagai hal terkait keangkatanlautan. Tidak hanya komunikasi dan koordinasi antarinstitusi negara (luar maupun dalam negeri), tetapi juga dengan organisasi di luar TNI, masyarakat dan antarprajurit TNI AL. Untuk itu diperlukan berbagai sarana komunikasi yang efektif dan efisien guna menunjang berlangsungnya komunikasi secara terus menerus. Komunikasi secara langsung dibatasi oleh waktu, tetapi komunikasi melalui logo berjalan sepanjang waktu.

Menyadari pentingnya komunikasi menggunakan logo, Dispenal menjadikan logo sebagai sarana penunjang berkomunikasi yang dapat memberikan semangat, kebanggaan, kebersamaan, identitas diri, dan sebagai simbol keteguhan dalam melaksanakan tugas guna mewujudkan visi misi TNI Angkatan Laut.

Logo diharapkan dapat menciptakan kesan utama yang berlangsung secara konsisten di seluruh jajaran penerangan TNI Angkatan Laut. Melalui logo diharapkan terjadi komunikasi antara TNI Angkatan Laut dengan masyarakat dan dengan prajurit TNI AL maupun Pegawai Negeri Sipil (PNS) di lingkungan TNI Angkatan Laut. Penggunaan logo tersebut merupakan salah satu bentuk komunikasi non verbal.

Penelitian semiotika terkait pemaknaan sebuah logo bukanlah hal yang baru dalam studi komunikasi khususnya di Indonesia. Banyak studi telah dilakukan baik dengan menggunakan semiotika model Charles Sanders Pierce, Roland Barthes, Ferdinand de Saussere, maupun modelmodel lainnya. Namun studi ini merupakan yang pertama kali membahas logo terkait institusi militer yang diharapkan dapat menjadi novelty penelitian.

Model Semiotika Pierce digunakan untuk memahami makna yang tersembunyi pada logo Dispenal sehingga dapat diketahui representament, object, dan penggunaan tanda (interpretant) yang ada di balik logo Dinas Penerangan TNI Angkatan Laut.

Dari penjelasan tersebut, maka rumusan penelitian ini adalah bagaimana representasi makna yang terkandung dalam logo Dispenal? Bagaimana pula peran logo Dispenal tersebut dalam mendorong efektivitas penerangan TNI AL guna membangun citra TNI Angkatan Laut.

\section{KERANGKA TEORI}

Teori utama yang digunakan pada penelitian ini adalah semiotika, yaitu ilmu tentang tanda (sign) baik tanda verbal ataupun visual. Semiotika juga mempelajari sistem-sistem, aturan-aturan, konvensikonvensi yang memungkinkan tanda-tanda tersebut mempunyai arti (Pradopo, 2003, Budiman, 2011). Semiotika dikelompokkan menjadi tiga cabang ilmu tentang tanda, yaitu Semantics, Syntatics, dan Pragmatics. Semiotika membantu kita memahami bagaimana cara berkomunikasi, membantu menerangkan kebiasaan dan kaidah-kaidah di semua unsur yang membentuk lingkungan komunikasi.

Dalam semiotika dikenal beberapa teori dan model, yaitu Charles Sanders Pierce, Ferdinand De Saussure, Roland Barthes, John Fiske, dan Umberto Eco. Pada penelitian ini, digunakan semiotika model Charles Sanders Pierce yang mendefinisikan semiotika sebagai studi tentang tanda dan segala sesuatu yang berhubungan dengan: cara berfungsi, hubungannya dengan tanda-tanda lain, pengiriman 
dan penerimaan oleh mereka yang mempergunakannya (Van Zoest dalam Rusmana, 2004, Barthes, 2017).

Semiotika model Pierce meliputi triadic, dikenal sebagai segitiga makna yang saling berhubungan satu sama lain, meliputi Representament sebagai tanda (sign) kemudian Interpretant, dan Object (Vera, 2014). Representament disebut sebagai sign bila mewakili tanda tertentu yang dapat dipersepsikan oleh pancaindra, perasaan maupun pikiran manusia. Interpretant, merupakan makna sign, namun bukan penafsir tanda, tetapi lebih kepada upaya validitas tanda. Interprestasi tanda ada pada kuasa pikiran yang dipahami representament. Object merujuk pada tanda yang diwakili representament berupa representasi tanda yang ada dalam pikiran, namun dapat pula berupa hal-hal nyata di luar tanda. Semiotika model Pierce secara singkat disebut sebagai hubungan antara tanda, obyek, dan makna dalam satu segitiga trikotomi: interpretant, representament, dan object (Gambar $1)$.

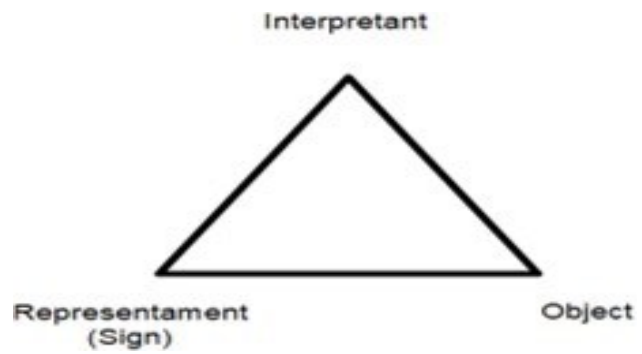

Gambar 1. Model Segitiga Makna Pierce

Sumber: Nawiroh Vera, 2014

Representament (Sign) sebagai trikotomi pertama terdiri atas: (1) Qualisign, yaitu kualitas tertentu yang kemudian dibentuk menjadi tanda, misalnya, "kursi" bila dihubungkan dengan "politik" maka "kursi" memiliki kualitas sebagai qualisign yang bermakna sebagai "kekuasaan"; (2) Sinsign, merupakan kondisi tertentu yang sudah ada sebagai representament tetapi belum berfungi sebagai sign, misalnya berteriak, menyanyi dan lain-lain; (3) Legisign, tanda (representament) yang sudah berlaku umum seperti rambu-rambu lalu lintas.

Trikotomi kedua adalah Interpretant, terdiri atas tiga tahapan yang berhubungan dengan sign yakni: (1) Rheme, penafsir sesuai pilihan ataupun kemungkinan yang tersedia; (2) Decisign, suatu tanda sesuai informasi sesungguhnya, seperti tanda lalu lintas tentang jalan menurun, dan (3) Argument, yakni sign dengan alasan yang berlaku sebagai kaidah, seperti tanda dilarang merokok di lingkungan kampus.

Untuk trikotomi ketiga, Object, meliputi ikon, indeks, dan simbol. Ikon merupakan gambaran dalam bentuk linguistik, citra atau image. Indeks adalah tanda yang memiliki keterkaitan fenomenal antara representament dengan objeknya sedangkan Simbol merupakan sesuatu yang dapat menyimbolkan dan mewakili ide, pikiran, perasaan, benda, namun acuan pada objek bukan karena kemiripan ataupun hubungan sebab akibat tapi merupakan kesepakatan sosial.

\section{Konsep Logo}

Lambang atau logo adalah elemen grafis yang berbentuk ideogram, simbol, emblem, ikon, tanda yang digunakan sebagai lambang sebuah brand. Logo merupakan atribut utama brand yang terlihat secara fisik. Logo yang baik harus dapat menampilkan semua atribut nonfisik yang merupakan jiwa dari brand (visi misi, nilai, budaya).

Logo dapat berupa huruf atau lambang yang mengandung suatu makna terdiri atas satu kata atau lebih sebagai lambang atau nama perusahaan. Dalam pengertian lainnya, logo atau tanda gambar merupakan identitas yang dipergunakan untuk menggambarkan citra dan karakter suatu lembaga atau perusahaan maupun organisasi (Kusrianto, 2009). Logo yang ideal secara keseluruhan merupakan suatu instrumen rasa harga diri dan nilai-nilai yang mampu mewujudkan citra positif dan bonafiditas. Pada akhirnya, logo adalah refleksi citra bisnis perusahaan, institusi, lembaga dan lain sebagainya yang disimbolisasikan serta direpresentasikan secara utuh dan total (Surianto, 2013). Logo juga bukan monopoli lembaga-lembaga swasta komersial tetapi juga berlaku pada instansi pemerintah. 
Peraturan Menteri Pendayagunaan Aparatur Negara Nomor 80 Tahun 2012 Tentang Pedoman Tata Naskah Dinas menyatakan, logo adalah tanda pengenal atau identitas berupa simbol maupun huruf yang digunakan dalam tata naskah dinas instansi pemerintah sebagai identitas agar publik lebih mudah mengenalnya.

Logo merupakan perwakilan atau wajah dari suatu perusahaan/instansi untuk mendapatkan efek positif terhadap citra perusahaan secara keseluruhan. Untuk itu dalam menentukan atau merancang sebuah logo perlu suatu perencanaan yang baik. Sebagai salah satu identitas perusahaan, logo dapat melakukan transformasi citra dan mempengaruhi cara pandang keseluruhan khalayak mengenai perusahaan.

Sebagus apa pun logo, jika tidak dapat menunjukkan lembaga yang diwakilinya, maka ia tidak lebih dari simbol tanpa arti. Jika sebuah logo mewajibkan khalayak untuk menduga-duga maknanya, maka logo itu gagal sebagai instrumen komunikasi. Itu sebabnya banyak perusahaan besar tidak hanya mencantumkan nama, tetapi juga slogan yang mengisyaratkan jenis bisnis, falsafah operasi, atau reputasi yang ingin diraihnya. Identitas perusahaan merupakan salah satu bentuk komunikasi yang paling tua (Anggoro, 2001).

Menurut Carter (dalam Kurniawan, 2008; Puspita, 2019), logo adalah identitas perusahaan dalam bentuk visual yang diaplikasikan dalam berbagai sarana dan kegiatan perusahaan sebagai bentuk komunikasi visual. Logo dapat juga disebut sebagai simbol, tanda gambar, merek dagang (trademark) yang berfungsi sebagai identitas diri badan usaha dan tanda pengenal berciri khas perusahaan.

\section{Corporate Identity}

Identitas korporasi (corporate identity) dirancang untuk memfasilitasi pencapaian tujuan bisnis yang diwujudkan sebagai branding dan merek dagang (Rachmawati et al, 2018). Corporate Identity merupakan identitas yang membedakan antara satu perusahaan dengan perusahaan lainnya, dan bisa juga berfungsi sebagai penanaman citra sebagai daya tarik. Identitas perusahaan berdasarkan filosofi organisasi terwujud dalam budaya perusahaan yang berbeda.

Tujuan corporate identity agar masyarakat mengetahui, mengenal, merasakan, dan memahami filosofi organisasi atau perusahaan (Balmer, 1995, Kholisoh \& Priamsari, PR., 2018). Corporate identity mempunyai beberapa fungsi: (1) sebagai patokan dari program menyeluruh dan strategi perusahaan; (2) sebagai landasan dari sistem operasional suatu perusahaan; (3) sebagai tiang dari jaringan (network) yang baik bagi perusahaan; dan (4) sebagai alat jual dan promosi.

Corporate identity terdiri dari tiga bagian yaitu corporate visual (logo, seragam, dan lain-lain), corporate communication (iklan, public relations, informasi, publikasi), corporate behaviour (nilainilai internal, norma-norma, dan lain-lain). Selain corporate indentity unsur lain yang harus ada dalam suatu perusahaan adalah branding yaitu suatu program yang memfokuskan dan memproyeksikan nilainilai merek. Program ini meliputi penciptaan pembedaan antara produk dan pelanggan dalam proses pengambilan keputusan pembeli serta pemberian nilai-nilai pada perusahaan. Jadi branding merupakan keseluruhan proses dalam memilih unsur, nilai hingga janji yang dimiliki oleh suatu entitas (produk, jasa, perusahaan). Branding adalah proses disiplin yang digunakan untuk membangun kesadaran dan memperluas loyalitas pelanggan (Swasty, 2016, Widita et.al, 2019).

\section{METODE PENELITIAN}

Penelitian ini menggunakan analisis semiotika Charles Sanders Pierce dengan pendekatan kualitatif untuk memahami fenomena yang dialami oleh subjek penelitian secara holistik, dan dengan cara deskriptif dalam bentuk kata-kata dan bahasa, pada suatu konteks khusus yang alamiah dengan memanfaatkan berbagai metode alamiah (Moleong, 2011, Arikunt, 2010, Creswell, 2014, Kriyantono, 2006, Sobur, 2016). Peneliti berusaha menyelidiki, mempelajari dan menggambarkan atau melukiskan bagaimana makna yang terkandung dalam logo Dispenal, dan bagaimana peran logo dalam mendorong efektivitas penerangan yang diemban Dispenal sehingga dapat membangun citra TNI Angkatan Laut.

Untuk mengungkap makna dari tanda objek yang sedang dianalisis, peneliti mengumpulkan data yang berasal dari perpustakaan umum, perpustakaan TNI Angkatan Laut, arsip Dinas Penerangan TNI Angkatan Laut, dan media online. Data tersebut berupa buku- buku, tesis, jurnal, skripsi, serta penelitian terdahulu serta data mengenai logo Dinas Penerangan TNI Angkatan Laut.

Setelah itu, peneliti melakukan pencatatan, mencari file-file yang ada hubungannya dengan judul penelitian yaitu tentang semiotika dan tentang logo. Semua sumber dikumpulkan, dibaca, dan dilakukan pemilihan, kemudian dihimpun menurut jenis dan kelompoknya, lalu dilaksanakan 
pengelolaan dan analisis data dengan cara deskriptif kualitatif. Selanjutnya diterjemahkan ke dalam kalimat-kalimat menjadi bahan penelitian yang bisa disusun dan disajikan sebagai laporan penelitian.

\section{HASIL PENELITIAN}

TNI Angkatan Laut berdiri tahun 1945 dengan nama Badan Keamanan Rakyat (BKR) Laut, kemudian menjadi Tentara Keamanan Rakyat (TKR) Laut dan Angkatan Laut Republik Indonesia (ALRI). Fungsi penerangan sudah ada pada tahun 1945 dengan nama Bagian Penerangan. Pada tahun 1963 ketika organisasi angkatan laut dipimpin oleh Menteri/Panglima Angkatan Laut, bagian penerangan berubah menjadi Pusat Penerangan Angkatan Laut. Sejak 1984 hingga sekarang namanya menjadi Dinas Penerangan TNI Angkatan Laut (Dispenal). Perubahan itu diikuti pula dengan perubahan logo yang beberapa kali mengalami perubahan menyesuaikan situasi dan keadaan pada masa itu.

Logo Dispenal sebelumnya menampilkan ikan lumba-lumba membawa kamera dalam suatu lingkaran disertai gambar kapal perang. Lingkarannya berwarna biru dengan tulisan "Dinas Penerangan TNI Angkatan Laut" berwarna merah (Gambar 2). Logo itu berubah total. Unsur lingkaran masih ada, namun dalam bentuk kemudi kapal berwarna kuning emas. Gambar kapal perang diganti sebuah jangkar berwarna emas di depan kemudi. Ikan lumba-lumba membawa kamera diganti dengan tokoh karton pelaut dalam serial televisi Popoye the Sailor Man serta tulisan "Dinas Penerangan TNI Angkatan Laut" diubah jadi "Dispenal" berwarna putih dalam suatu pita berwarna biru gelap (Gambar $3)$.

Logo tersebut mengalami perubahan Kembali dengan tetap mempertahankan gambar kemudi kapal namun dalam warna kuning yang lebih terang. Logo terbaru ini tidak lagi menampilkan gambar Popeye tetapi mengubahnya dengan simbol lencana perang TNI AL berwarna merah-putih dilengkapi bola dunia dan pita warna biru gelap dengan tulisan "Cepat Tepat Akurat" (Gambar 4). Logo tersebut masih berlaku hingga sekarang, dan menjadi obyek pada penelitian ini.

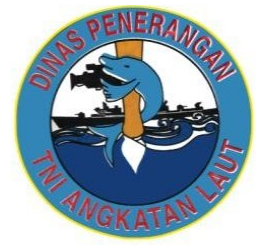

Gambar 2. Logo Dispenal Lama Sumber: Dispenal

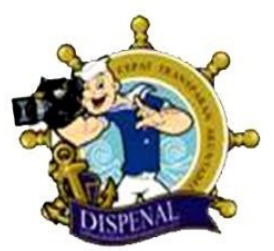

Gambar 3. Logo Dispenal Lama Sumber: Dispenal

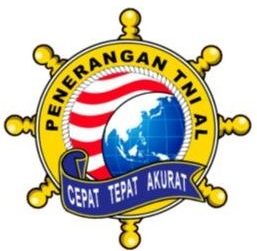

Gambar 4. Logo Dispenal Baru Sumber: Dispenal

Berdasarkan analisis semiotika Charles Sanders Pierce dengan model triadic dan konsep trikotomi, representamen, interpretant, dan object, logo Dispenal mencerminkan identitas dari TNI AL dan merupakan tanda yang dapat mewakili pikiran masyarakat terhadap TNI AL. Tanda-tanda yang dibahas dalam penelitian ini terbatas pada ikon, indeks, dan simbol berdasarkan semiotika Pierce. Ikon dalam logo Dispenal antara lain kemudi, dan lencana perang. Indeks dalam logo Dispenal itu antara lain bola dunia, kemudi kapal bertuliskan "Penerangan TNI AL", lencana perang merah putih, dan pita seperti gelombang bertuliskan "Cepat Tepat Akurat". Sedangkan Simbol dalam logo Dispenal antara lain warna kuning, merah putih, biru.

Pierce melihat tanda (representament) sebagai bagian yang tidak terpisahkan dari objek referensinya serta pemahaman subjek atas tanda (interpretant). Tanda dalam pandangan Pierce selalu berada di dalam proses perubahan tanpa henti yang disebut proses semiosis tak berbatas (unlimited semiosis), yaitu proses penciptaan rangkaian interpretant yang tanpa akhir di dalam sebuah rantai produksi dan reproduksi tanda, yang di dalamnya tanda mendapatkan tempat hidup, bertumbuh, dan berkembang. Dalam logo Dispenal, bola dunia dan peta yang berada di dalam lingkaran kemudi, serta pita dengan lambaian seperti gelombang menjadi bagian yang tidak terpisahkan. Tanda dalam logo Dispenal merupakan semiosis tak berbatas.

Logo Dispenal adalah bagian dari cerminan visi dan misi TNI AL yang digambarkan dengan bentuk, warna, dan tipografi yaitu kemudi berwarna kuning, lencana perang berwarna merah putih, bola dunia dan peta berwarna biru, serta pita berwarna biru. Arti dari warna lambang, kuning berarti bijaksana, merah putih diartikan sebagai semangat pantang menyerah dan penuh keikhlasan, dan warna biru yang berarti loyalitas, kesetiaan, dan ketaatan. 
Dalam kemudi bertuliskan "PENERANGAN TNI AL" melambangkan jati diri sebagai ujung tombak penerangan TNI AL. Kemudi kuning melambangkan personel penerangan TNI AL adalah insan yang bijaksana dalam menghadapi tantangan penugasan dan senantiasa teguh menjaga arah kebijakan pemimpin dan organisasi TNI AL. Selain itu, komunitas Penerangan TNI AL senantiasa siap mengamankan kebijakan pimpinan. Lencana Perang berwarna merah putih dalam lingkaran kemudi, melambangkan TNI AL senantiasa menjadikan setiap penugasan sebagai kehormatan dan kebanggaan.

Komunitas penerangan TNI AL dalam menjalankan penugasan senantiasa dilandasi semangat pantang menyerah dan penuh keikhlasan. Bola Dunia biru melambangkan personel penerangan TNI AL senantiasa dituntut menjadi insan yang berwawasan global guna mendukung visi TNI AL yang handal dan disegani serta berkelas dunia. Bola dunia dan peta dunia melambangkan komunitas penerangan TNI AL adalah bagian yang tidak terpisahkan dari komponen bangsa.

Pita biru bertuliskan motto, "CEPAT TEPAT AKURAT", bermakna menegaskan bahwa komunitas penerangan TNI AL adalah ujung tombak terdepan dalam pembinaan fungsi penerangan TNI AL yang senantiasa dituntut bekerja secara cepat, tepat, dan akurat. Cepat dalam mengantisipasi, menangani, dan menindaklanjuti berbagai isu dan opini yang berkembang, tepat dalam memberikan solusi berbagai permasalahan, serta akurat dalam menyampaikan setiap informasi dan opini. Pita dengan lambaian seperti gelombang melambangkan TNI AL penuh inisiatif, kreatif, dan inovatif dalam menghadapi dinamika penugasan.

Di dalam logo, melekat aturan-aturan secara hukum dan menggambarkan sistem dari organisasi TNI AL, termasuk visi dan misi. Visi TNI AL adalah terwujudnya TNI AL yang handal dan disegani, sedangkan misinya adalah membina kekuatan dan kemampuan TNI AL yang berkelanjutan secara efektif dan efisien; menjamin tegaknya kedaulatan dan hukum, keamanan wilayah laut, keutuhan wilayah NKRI, serta terlaksananya diplomasi Angkatan Laut dan pemberdayaan wilayah pertahanan laut; mewujudkan personel TNI AL yang bermoral dan profesional; mewujudkan kekuatan TNI AL menuju kekuatan pokok minimum (Minimum Essential force/MEF); menjamin terlaksana tugas-tugas bantuan kemanusiaan; mewujudkan organisasi TNI AL yang bersih dan berwibawa; mewujudkan keluarga besar TNI AL yang sehat dan sejahtera.

Logo Dispenal adalah bagian implementasi dari Peraturan Menpan dan Reformasi Birokrasi Nomor 80 Tahun 2012, sebagai institusi pemerintah penyelenggara pemerintahanan, yang memiliki berbagai aktivitas, terutama berkaitan dengan regulasi, pelayanan publik, serta penyediaan fasilitas umum. Pemerintah yang berfungsi sebagai penyedia pelayanan umum harus memiliki citra institusi yang baik, terpercaya, kredibel, dan memiliki reputasi yang baik. Melalui pembentukan logo juga dapat berperan sebagai salah satu prime mover perubahan budaya kerja dalam instansi pemerintah yang akan membantu membentuk persepsi masyarakat (consumer imagery) terhadap instansi pemerintah tersebut (HAKI, 2013). Persepsi demikian terbentuk dari upaya pembangunan citra insitusi pemerintah. Hal itu menjadi gambaran mental dalam benak masyarakat dan pihak swasta mengenai institusi pemerintah. Jika persepsi melekat dalam waktu lama, akan membentuk citra. Logo instansi selalu memiliki nilai simbolik secara individu yang didasarkan pada konsistensi kinerja institusi (Rustan, 2013, Irwansyah, 2016).

Konsep dan definisi logo yang dikemukakan sejumlah ahli komunikasi dan akademisi sejalan dengan tujuan Dispenal dengan pembuatan logo. Perubahan logo yang terjadi dianggap perlu setelah melakukan evaluasi. Tentu saja terdapat perbedaan besar dalam perubahan logo instansi pemerintah seperti Dispenal ini dengan perubahan logo pada institusi swasta komersial. Pada institusi pemerintah lebih mengedepankan identitas, selain visi, misi dan motivasi. Berbeda dengan logo swasta komersial yang lebih kepada branding, dan soal cerminan semangat, profesionalitas dan profit.

Logo merupakan salah satu bentuk simbol yang secara spesifik digunakan sebagai identitas suatu entitas baik pemerintah maupun swasta. Febriansyah dan Nuzul Inas Nabila dalam penelitiannya terhadap logo PT. Telkom menyimpulkan bahwa logo dapat mempengaruhi citra perusahaan. Karena itu perubahan logo berpengaruh secara signifikan terhadap citra.

Citra merupakan salah satu aset penting bagi organisasi yang harus terus menerus dibangun dan dipelihara. Citra juga menunjukkan sebuah eksistensi di mata publik, yaitu menunjukkan pandangan masyarakat terhadap organisasi yang terbentuk dalam jangka waktu panjang. Kesan dan pengetahuan masyarakat mengenai organisasi akan membentuk citra organisasi tersebut. Pencitraan yang terbentuk dengan baik akan memberikan dampak yang baik pula demi tercapainya tujuan yang ditetapkan 
organisasi.

Menurut Kamus Besar Bahasa Indonesia (1996), citra adalah gambaran yang dimiliki orang banyak mengenai pribadi, perusahaan, organisasi, atau produk. Sedangkan menurut Kazt, citra adalah cara bagaimana pihak lain memandang sebuah perusahaan, seseorang, suatu komite, atau suatu aktivitas. Kazt juga mengutip Frank Jefkins, citra diartikan sebagai kesan seseorang atau individu tentang sesuatu yang muncul sebagai hasil dari pengetahuan dan pengalamannya. Jalaludin Rakhmad mendefinisikan citra sebagai gambaran tentang realitas dan tidak harus sesuai dengan realitas, citra adalah dunia menurut persepsi (Soemirat et al, 2007., Jefkins, 1995., Kasali, 2003).

Citra yang diciptakan dipandang sebagai salah satu aset terpenting yang dimiliki oleh perusahaan atau organisasi. Menurut Zinkhan, ada beberapa alasan yang mendasari pentingnya perusahaan membangun dan mengelola citra perusahaan atau organisasi, yaitu dapat merangsang penjualan, dapat membangun nama baik perusahaan, membangun identitas bagi karyawannya, mempengaruhi investor dan lembaga-lembaga keuangan, memajukan hubungan baik dengan suatu komunitas, dengan pemerintah, dengan tokoh masyarakat dan dengan para opinion leaders, mendapatkan posisi dalam persaingan.

Berdasarkan pengertian para pakar tersebut, citra dapat diartikan sebagai gambaran yang diperoleh oleh lingkungan di sekitar atau pihak lain sebagai hasil dari pengalaman dan pengetahuannya tentang suatu objek. Citra adalah sesuatu yang ditonjolkan secara nyata yang timbul berdasarkan pengetahuan dan pengalaman yang ada. Citra itu dengan sengaja perlu diciptakan agar bernilai positif.

Dari deskripsi, teori-teori, pendapat pakar serta berbagai hasil penelitian dapat dijadikan justifikasi mengenai efektivitas logo dalam meningkatkan citra suatu lembaga pemerintah/swasta maupun perusahaan. Logo menjadi salah satu upaya peningkatan citra maupun cita-cita dalam meningkatkan kinerja dan mewujudkan visi maupun misi lembaga.

Namun dalam membangun citra positif organisasi bukanlah hal yang mudah, membutuhkan suatu proses yang panjang karena citra terbentuk berdasarkan informasi-informasi yang diterima seseorang dan merupakan persepsi yang dibentuk oleh masyarakat. Citra dan kepercayaan yang baik di mata masyarakat merupakan salah satu hal yang terpenting bagi eksistensi suatu organisasi. Apabila citra dan kepercayaan organisasi rusak di mata masyarakat akan berdampak negatif dan akan terus berkepanjangan, selain itu juga tingkat kepercayaan masyarakat menjadi turun secara tajam.

\section{KESIMPULAN}

Berdasarkan hasil pembahasan, dapat ditarik kesimpulan bahwa tanda yang terdapat pada bentuk, warna, dan tipografi logo Dispenal sesuai dengan visi dan misi TNI Angkatan Laut. Makna warna yang terdapat pada logo Dispenal adalah suatu upaya yang dapat memberikan semangat pantang menyerah dan penuh keikhlasan, dengan loyalitas, kesetiaan, dan ketaatan yang dilaksanakan secara bijaksana. Moto Cepat Tepat Akurat, menegaskan komunitas penerangan TNI AL merupakan ujung tombak terdepan dalam pembinaan fungsi penerangan TNI AL yang dituntut bekerja secara cepat, tepat, dan akurat. Cepat dalam mengantisipasi, menangani, dan menindaklanjuti berbagai isu dan opini yang berkembang tentang TNI AL. Tepat dalam memberikan solusi berbagai permasalahan, serta akurat dalam menyampaikan setiap informasi dan opini.

Bentuk kemudi berwarna kuning dilambangkan bahwa personel penerangan TNI AL adalah insan yang bijaksana dalam menghadapi berbagai tantangan penugasan dan teguh menjaga arah kebijakan pemimpin dan organisasi TNI AL, serta siap mengamankan kebijakan pimpinan. Bola dunia berwarna biru memiliki makna untuk menjadikan setiap penugasan sebagai kehormatan dan kebanggaan, dengan dilandasi semangat pantang menyerah dan penuh keikhlasan. Personel penerangan dituntut menjadi insan yang berwawasan global untuk mendukung visi TNI AL yang handal dan disegani serta berkelas dunia, serta turut bertanggung jawab dalam menggelorakan pembangunan kemaritiman menuju Indonesia sebagai poros maritim dunia.

Pita berwarna biru dengan tulisan Penerangan TNI AL, memiliki makna bahwa sebagai ujung tombak, Dispenal dituntut untuk penuh inisiatif, kreatif, dan berinovasi dalam menghadapi dinamika penugasan, serta bertanggung jawab dalam membangun komunikasi dan informasi guna mendukung tugas pokok TNI AL sebagai komponen utama pertahanan negara.

Dari makna yang terkandung dalam logo tersebut dapat tercermin visi dan misi TNI Angkatan Laut yang dilaksanakan oleh insan penerangan yang memiliki semangat pantang menyerah dan penuh keikhlasan, dengan loyalitas, kesetiaan, dan ketaatan. Dengan demikian logo sangat berperan terhadap 
fungsi penerangan yang dapat membangun citra TNI Angkatan Laut. Logo Dispenal yang ada saat ini menjadi simbol yang melekat di dalam dinamika tugas sehari-hari, karena dapat memberikan dorongan moril serta kebanggaan bagi para personel Dispenal dalam melaksanakan tugasnya.

\section{DAFTAR PUSTAKA}

Anggora, M.A.L. (2001). Teori dan Profesi Kehumasan. Jakarta: PT. Bumi Aksara. Arikunt, S. (2010). Prosedur Penelitian: Suatu Pendekatan Praktis. Jakarta: Rineka Cipta Barthes, R. (2017). Elemen-Elemen Semiologi. Yogyakarta: Basabasi

Budiman, K. (2011). Semiotika Visual. Yogyakarta: Jala Sutra

Creswell, J.W. (2014). Penelitian Kualitatif \& Desain Riset. Yogyakarta: Pustaka Pelajar. Effendy, O.U. (2001). Ilmu Komunikasi: Teori dan Praktek. Bandung. Remaja Rosdakarya. Irwansyah, (2016). Perspektif Triplehelix dalam Nation Brand Indonesia, Jurnal Komunikasi Ikatan Sarjana Komunikasi Indonesia, 1(2), 81-98.

Jefkins, F. (1995). Public Relations. Jakarta: Erlangga.

Kasali, R. (2003). Manajemen Public Relations. Jakarta: Grafiti.

Kriyantono, R. (2006). Teknik Riset Komunikasi. Jakarta: Kencana.

Kurniawan, D. (2008). Perancangan Logo dan Maskot untuk Mendukung Promosi Wisata Kuliner Malam Warung Tradisional di Surabaya, Surabaya: Universitas Kristen Petra.

Kusrianto, A. (2009). Pengantar Desain Komunikasi Visual. Yogyakarta: Andi Offset Littlejohn, S.W \& Karen A.F. (2018). Teori Komunikasi. Jakarta: Salemba Humanika Mulyana, D. (2017). Ilmu Komunikasi Suatu Pengantar. Bandung: PT. Remaja Rosdakarya.

Moleong J.L. (2011). Metodologi Penelitian Kualitatif. Bandung: Remaja Rosdakarya Murphy, J., Rowe, M. (1998). How to Design: Trademarks and Logos. North Light Books.

Kholisoh, N \& Priamsari, PR. (2018). Strategi Komunikasi untuk Meraih the Best Branch Service Excellent pada Bank Mandiri Jakarta Cikini. Warta Ikatan Sarjana Komunikasi Indonesia, 1(2), 41-56.

Puspita, IM. (2019). Marketing Public Relation Peremajaan Merek sebagai Stategi Pemasaran dalam Membangun Citra Produk Baru. Warta Ikatan Sarjana Komunikasi Indonesia, 2(1), 19-26.

Pradopo, Rachmat Djoko. Dkk, 2003. Metodologi Penelitian Sastra. Yogyakarta: PT Hanindita Graha Widya.

Rachmawati, D \& Ali, D.S.F (2018). Analisis Personal Branding Selegram Nonselebriti Akun Instragram@Lippielust. Warta Ikatan Sarjana Komunikasi Indonesia, 1(1), 34-40.

Rusmana, D. (2014). Filsafat Semiotika Paradigma, Teori, dan Metode Intrepretasi Tanda dari Semiotika struktural hingga Dekonstruksi Praktis. Bandung: CV Pustaka Setia.

Rustan, S. (2013). Mendesain Logo. Jakarta: PT Gramedia Pustaka Utama.

Sobur, A. (2016). Semiotika Komunikasi. Bandung: PT Remaja Rosdakarya

Soemirat, S \& Ardianto, E. (2004). Dasar-Dasar Public Relations. Bandung: Remaja Rosdakarya.

Vera, N. (2014). Semiotika dalam Riset Komunikasi. Bogor: Ghalia Indonesia.

Widita, A., Kusuma, Y., Husna, N \& Sagita G. (2019). The Heart of East Java: Branding Pariwisata Humas Pemerintah Kabupaten Malang. Warta Ikatan Sarjana Komunikasi Indonesia, 2(2), 117123. 